Çukurova Üniversitesi Mühendislik Mimarlık Fakültesi Dergisi, 34(3), ss. 271-282, Eylül 2019

Çukurova University Journal of the Faculty of Engineering and Architecture, 34(3), pp. 271-282, September 2019

\title{
Van İlindeki Tehlikeli Atıkların Mevcut Potansiyelinin Belirlenmesi
}

\author{
Dilara ÖZTÜRK*1 \\ ${ }^{1}$ Van Yüzüncü Yıl Üniversitesi, Mühendislik Fakültesi, Çevre Mühendisliği Bölümü, Van
}

Geliş tarihi: 31.07 .2019

Kabul tarihi: 30.09 .2019

$\ddot{\mathbf{O} z}$

Hızla artan insan nüfusu ile paralel olarak gelişen bilim ve teknolojinin bir sonucu olarak ortaya çıkan endüstrileşme, beraberinde çevre kirliliğini de getirmektedir. Çevre kirliliğine sebep olan ve yaşamsal faaliyetleri doğrudan etkileyen en önemli kirleticilerden biri de tehlikeli atıklardır. Bu çalışmanın amacı Van ilindeki tehlikeli atıkların mevcut potansiyelini belirlemek, şehrin tehlikeli atık yönetimi ile ilgili sorunlarını tespit etmek ve çözüm önerileri sunmaktır. Elde edilen veriler ışı̆̆ında kentte atık madeni yağların neredeyse tamamının geri kazanıldığı, kazanılan atık yağın büyük miktarının tesis içi atık minimizasyonu ile sağlandığı; 2018 yılına kadar tıbbi atıkların bir sterilizasyon tesisinde evsel nitelik kazandırıldıktan sonra vahşi depolama alanlarında bertaraf edildiği ancak kurulumuna başlanan katı atık entegre tesisinde daha güvenli bertarafının planlandı̆̆ı; kentin atık elektrikli ve elektronik eşyalar için herhangi bir eylem planının bulunmadığı; Ayrıca, toplanan atık pil ve akümülatörlerin ve ömrünü tamamlamış lastiklerin sayısı göz önüne alındığında tam bir geri dönüşümün sağlanmadığı sonucuna varılmıştır. Atık elektrikli ve elektronik eşyaların geri dönüşüme kazandırılması için çevre mevzuatı kapsamında gerekli izin ve lisansları bulunan firmalar ile iş birliği içerisine girilmesi gerektiği sonucuna varılmıştır. Ayrıca toplanan atık pil ve akümülatörlerin ve ömrünü tamamlamış lastiklerin il genelinde etkin toplanması için; büyük şehir belediyesinin, ilçe belediyelerinin çalışmalarını koordine etmesi ve konuyla ilgili yürütülen bilgilendirme ve eğitim faaliyetlerini desteklemesi gerektiği sonucuna varılmıştır.

Anahtar Kelimeler: Bertaraf, Geri dönüşüm, Tehlikeli atık, Van

\section{Determination of Current Potential of Hazardous Wastes in Van Province}

\begin{abstract}
Industrialization, which emerged as a result of science and technology developing in parallel with rapidly increasing human population, brings environmental pollution with it. One of the most important pollutants that cause environmental pollution and directly affect vital activities is hazardous waste. The aim of this study is to determine the existing potential of hazardous wastes in Van province, identify problems related to hazardous waste management of the city and offer solutions. In the light of the data obtained, almost all of the waste mineral oils are recovered in the city and the large amount of waste oil obtained is provided by in-plant waste minimization; Until 2018 medical wastes were disposed of in a wild landfill site after being qualified as a household in a sterilization facility, but the safer disposal of the
\end{abstract}

*Sorumlu yazar (Corresponding author): Dilara ÖZTÜRK, dozturk@yyu.edu.tr 
solid waste integrated plant was planned; Also, it is concluded that the city does not have any action plan for waste electrical and electronic equipment and considering the number of waste batteries and accumulators collected and the tires that have reached the end of their life, no complete recycling is provided. It is concluded that in order to recycle waste electrical and electronic materials, it should be entered into cooperation with the companies with the necessary permits and licenses within the scope of environmental legislation. Also, for the efficient collection of waste batteries and accumulators and out of-life tires throughout the province; It is concluded that the metropolitan municipality should coordinate the work of the district municipalities and support the information and training activities carried out on the issue.

Keywords: Disposal, Recycling, Hazardous waste, Van

\section{GíRiș}

Değişen zamana paralel olarak gelişen dünyada endüstrileşmenin getirdiği en önemli problemlerden birisi de çevre kirliliğidir [1]. Günümüzde üretim ile neredeyse eș anlama gelmiş endüstrileşme, ülkelerin refah düzeyini artırması ve dışa bağımlılığını azaltması sebebi ile büyük önem taşımaktadır. Ancak ekolojik ve ekonomik kalkınmanın sağlanması ve sürdürülmesi için endüstri ve çevre entegrasyonunun sağlıklı bir çerçevede olması gerekmektedir. Dünya gündemini meşgul eden bu sorunun çözümü için yalnız gelişmiş ülkeler değil, aynı zamanda gelişmekte olan ülkeler de bazı ekonomik, teknik ve hukuki tedbirler alma mecburiyeti duymaktadırlar. Gerekli önlemlerin alınmadığı takdirde, sonsuz olmayan su kaynaklarının kirlenmesi ve tükenmesi, yine su kaynaklarını öz yenileme ve temizleme özelliklerini kaybetmesi, toksik birikimle üretme yeteneğini kaybetmiş ve kullanılamaz hale gelmiş toprak yapısı, solunması tüm canlı hayatı için artık zarar vermeye başlayan hava kompozisyonu ile sonuçlanacaktır.

Çevre kirliliğine sebep olan ve yaşamsal faaliyetleri doğrudan etkileyen en önemli kirleticilerden biri de tehlikeli atıklardır. Tehlikeli atıklar, geniş kapsamlı üretim işletmelerinden (üniversiteler, hastaneler, endüstriler vb.) küçük işletmelere kadar (laboratuvarlar, ev ve işyerleri, kuru temizleyiciler vb.) çeşitli kaynaklardan çıkan tehlikeli ve zararlı maddelerdir [2]. Atığın kimyasal kompozisyonu, miktarı, kimyasal reaktifliği, fiziksel yapısı ve çevre üzerindeki etkileri incelenerek tehlikeli olup olmadığına karar verilir. Ancak asıl belirleyici olan söz konusu atığın tehlikeli bir atığın dört özelliğinden (tutuşabilirlik, aşındırıcılık, reaktivite ve toksisite) herhangi birini sergileyip sergilemediğidir, bu özelliklerden herhangi birini sergileyen atık tehlikeli atık sınıfına dâhil olabilir [3].

\subsection{Atık Madeni Yağlar}

Atık yağlar, atık olarak oluşan ve kısmen veya tamamen mineral yağdan, sentetik veya biyojenik yağdan oluşan yağlardır [4]. Madeni yağlar mekanik araç ve gereçlerde özellikle yağlama amacı ile kullanılırlar belli bir süre sonra madeni yă̆ sürtünme, katı içerik oluşumu vb. gibi kimyasal ve fiziksel özellikleri bozulur ve yenileri ile değiştirilmesi gerekir. Bu bağlamda Avrupa Parlamentosu ve Konseyinin 19 Kasim 2008 tarihli ve 2008/98/EC sayılı atık yönergesinde, atık yağların ayrı toplanması, uygun bir atık yönetimi stratejisinin kabul edilmesi ve atık depolamadan kaynaklanan çevresel zararların önlenmesi gibi konular vurgulanmıştır. Ayrıca Atık yağların kontrolü yönetmeliği ile de bazı düzenlemeler yapılmıştır. Yönetmelik; I. II. ve III. kategori atık yağların üretimi, geçici depolanması, toplanması, taşınması, işlenmesi, bertarafı, ithalat ve ihracatı ile transit geçişine ilişkin yasak, sınırlama ve yükümlülükleri, alınacak önlemleri, yapılacak denetimleri kapsamaktadır [5].

2010-2011 yılları arasında yapılan araştırmalara göre [2], Türkiye'de yıllık ortalama 400-450 bin ton mineral yağ tüketilmektedir, tüketim sonras1 yaklaşık 200-250 bin tonu ise atık mineral yağ olarak ortaya çıkmaktadır. Kalan 200 bin ton yağ satın alınarak toplanmakta, 10 numara madeni yağ 
ad1 altında yakit olarak kullanılmakta veya kontrolsüz ortamlarda 1sitılmak üzere bir araya getirilerek elden çıkarılan diğer yakıtlarla karıştırılarak piyasaya kalifiye olmayan yağ olarak sunulmaktadır. Böylesi yağların tekrar kullanımı sonucu $\mathrm{SO}_{2}, \mathrm{NO}_{2}$ oranı çok yüksek emisyonlar atmosfere salınmakta ve hava kirliliğine ciddi katkıda bulunmaktadır. Ayrıca bu atıkların alıcı su ve toprak ortamına deşarjları sonucu alıcı ortamın fiziksel ve kimyasal yapılarının bozulmasına sebep olmakla beraber alıcı ortamda bulunan canlıların yaşamını tehdit etmektedirler.

\subsection{Bitkisel Atık Yağlar}

Bitkisel yağlar gıda sanayinde sıvı ve katı halde kullanıldığı gibi, deterjan, yem ve boya sanayinde sıklıkla kullanılmaktadır. Bitkisel yağların kullanılması sonucu bitkisel atık yağların bertarafına ilişkin önlemler almak Atık Yönetimi Yönetmeliği'nin ek-4 atık listesinde yer alan; "20 01 26*- 200125 dişındaki sıvı ve katı yağlar (A)" kodu kapsamında değerlendirilen kullanılmış kızartmalık yağlar ile "20 0125 - Yenilebilir sıvı ve katı yağlar" kodu kapsamında değerlendirilen diğer bitkisel atık yağları kapsayan yönetmelik yürürlüğe konulmuştur [6].

Ülkemizin yıllık bitkisel yağ kullanımı yaklaşık olarak; 950.000 ton siv1 yemeklik, 550.000 ton margarin, 200.000 ton civarında da yem, boya ve sabun sanayi olmak üzere yaklaşık 1,7 milyon tondur [7]. Bitkisel atık yağlar oldukça yüksek kaloriye sahiptir. Bu atık yağlar, alıcı ortama ya da kanalizasyon sistemlerine deşarj edildiği zaman su yüzeyinde oksijen transferini engelleyen bir tabaka oluştururlar ayrıca suda zamanla bozunmaya uğrayarak sudaki mevcut oksijenin tükenmesine sebep olurlar. $\mathrm{Su}$ yüzeyinden oksijen geçişi engellendiğinde ortamdaki canlı yaşam (balıklar, su bitkileri ve su canlıları) tehlikeye girer ve belirli bir süre sonra anaerobik türlerin baskın gelmesi ile sonuçlanır. Ayrıca kanalizasyon sistemleri ile atıksu arıtma tesisine ulaşan yağlı atıksular kanal borularına yapışarak boru kesitinin daralmasına ve tıkanmasına neden olarak tesisin işletme maliyetini artırır. Kullanılmış bitkisel ve hayvansal yağlar atık su kirliliğinin \%25'ini oluşturmaktadır [7].

\subsection{Atık Pil ve Akümülatörler}

Teknolojinin hızla gelişmesine paralel olarak teknolojik aletlerin üretimi ve kullanımı da artmıştır. $\mathrm{Bu}$ bağlamda 'Atık Pil ve Akümülatörlerin Kontrolü Yönetmeliği’ ile pil ve akümülatör ürünlerinin etiketlenmesi ve işaretlenmesi, üretilmesinde zararlı madde miktarının azaltılması, kullanıldıktan sonra atıklarının evsel ve diğer atıklardan ayrı olarak toplanması, taşınması, bertarafı ile ithalat, transit geçiş ve ihracatına ilişkin yasak, sınırlama ve yükümlülükleri, alınacak önlemleri, yapılacak denetimleri ve sorumlulukları düzenlenmiştir [8]. Pil ve akümülatör benzeri materyallerde ağır metal ve kimyasal maddeler gibi insan ve çevre sağlığını tehdit eden bileşenler bulunmaktadır (Çizelge 1).

Çizelge 1. Pillerin içerdiği elementlerin ağırlıkça \% kompozisyonu [9]

\begin{tabular}{|l|c|c|c|c|}
\hline $\begin{array}{l}\text { Pil } \\
\text { Türü }\end{array}$ & Kadmiyum & Civa & Gümüş & Çinko \\
\hline Alkali & 0,01 & 0,025 & 0,01 & $8-18$ \\
\hline $\begin{array}{l}\text { Çinko- } \\
\text { karbon }\end{array}$ & 0,03 & 0,01 & - & $12-20$ \\
\hline $\begin{array}{l}\text { Civa } \\
\text { oksit }\end{array}$ & - & $30-50$ & - & $10-15$ \\
\hline $\begin{array}{l}\text { Gümüş } \\
\text { oksit }\end{array}$ & - & $0,5-1$ & $30-45$ & $30-35$ \\
\hline $\begin{array}{l}\text { Çinko- } \\
\text { hava }\end{array}$ & - & $1-2$ & - & $35-40$ \\
\hline Lityum & - & - & - & - \\
\hline
\end{tabular}

Pil ve akümülatörlerin içerdiği ağır metaller insanlarda merkezi sinir sisteminin tahribine, kansere, böbrek, karaciğer, beyin dokularının tahribine ve sakat doğumlara neden olmaktadır [10]. Ağır metallerin yanında akümülatörlerin içeriğinde bulunarak elektrolit görevi yapan sıvilar $\left(\mathrm{KOH}, \mathrm{H}_{2} \mathrm{SO}_{4} \mathrm{vb}\right.$.) ekolojik sistemde bulunan tüm canlı yaşamı negatif yönde etkilemekte, alıcı ortam ve toprak kirliliğine sebep olmaktadır. Örneğin kullanılmış bir civa oksit pili 800.000 litre içme suyunu kirletmektedir [9].

\section{4. Ömrünü Tamamlamış Lastikler}

Artan araç sayısı ile lastik üretiminin artması hatta lastik kullanımının hayatın birçok alanına dâhil olması ile atık lastik miktarı da gittikçe artan bir 
potansiyele sahip olmuştur. Lastikler kimyasal kompozisyonu sebebi ile tehlikeli ve biyobozunmaz maddeler içermektedir. Lastiklerin en çok kullanıldığı alan olan otomobil lastiklerinin kimyasal kompozisyonu Çizelge 2'de verilmiştir [11].

Çizelge 2. Otomobil lastiklerinin kimyasal kompozisyonu [11]

\begin{tabular}{|l|c|}
\hline Malzeme & \% Bileşim \\
\hline Kauçuk/Elastomer & 47 \\
\hline Karbon Siyahı/Silika & 21,5 \\
\hline Metal & 16,5 \\
\hline Tekstil ürünü & 5,5 \\
\hline Çinko oksit & 1 \\
\hline Kükürt & 1 \\
\hline Katkı maddeleri & 7,5 \\
\hline
\end{tabular}

Çizelge 2'den de görülen biyobozunmaz bu maddelerin çevre ve insan sağlığına zararlarını önlemek için Çevre ve Şehircilik Bakanlığı tarafından 'Ömrünü Tamamlamış Lastiklerin Kontrolü Yönetmeliği' yürürlüğe girmiştir. Yönetmelik, ömrünü tamamlamış lastiklerin, çevreye zarar verecek şekilde doğrudan veya dolaylı olarak alıcı ortama verilmesinin önlenmesi, yeniden kullanımı veya bertarafı için toplama ve taşıma sisteminin kurulması, yönetim planının oluşturulması konularını kapsamaktadır [12].

ÖTL'lerin bertarafı kontrollü bir şekilde sağlanmadığı müddetçe bünyesinde bulunan bu tehlikeli bileşenleri zamanla çevreye salmakta ve bu tehlikeli maddeler ekolojik döngüye dahil olmaktadır.

\subsection{Atık Elektrikli ve Elektronik Eşyalar (AEEE)}

Gelişen ve değişen teknolojiye eş olarak artan elektronik eşyaların kullanımı bir taraftan insan hayatını kolaylaştırırken diğer taraftan tehdit etmektedir.

Atık Elektrikli ve Elektronik Eşyaların Kontrolü Yönetmeliğine göre AEEE; büyük ev eşyaları, küçük ev aletleri, bilişim ve telekomünikasyon ekipmanları, tüketici ekipmanları, aydınlatma ekipmanları, elektrikli ve elektronik aletler (büyük ve sabit sanayi aletleri hariç olmak üzere), oyuncaklar, eğlence ve spor aletleri, tıbbi cihazlar (emplantasyon ürünleri ve hastalık bulaşıcı temaslarda bulunan ürünler hariç), izleme ve kontrol aletleri ve otomat sinıflarına dâhil olan elektrikli ve elektronik eşyalar ile elektrik ampulleri ve evsel amaçlı kullanılan aydınlatma gereçlerini kapsamaktadır[13].

Ömrünü tamamlamış elektronik ürünlerin kullanımı enerji sarfiyatını arttırırken, AEEE' lerin uygun şekilde geri dönüştürülmemesi bu atıkların içeriğinde bulunan kurşun, civa, brom ve krom gibi ağır metallerin zamanla atmosfere, toprağa ve alıcı su ortamlarına salınmasına ve ekolojik döngü için toksik tehdit oluşturmasına sebep olmaktadır.

\subsection{Tıbbi Atıklar}

Tehlikeli atıklar sınıfına giren en önemli atıklardan biri de tıbbi faaliyetler sonucu ortaya çıkan atıklardır. Bu atıkların kaynak noktaları olan sağlık kurumları, oluşan atıkların hem yerinde hem de dışında etkilenen/etkilenecek olan kişilerin sağlığına ve çevreye sebep olacakları zararları minimize edebilmek için sınıflandırma, kaynağında ayrı, geçici depolama, taşıma, işleme ve nihai bertaraf aşamalarında uyulması gereken kurallar kapsamında 'Tıbbi atıkların kontrolü Yönetmeliği’ yürürlüğe girmiştir [14]. Tıbbi atıklar enfekte olmalarının yanında ilaçlar, radyoaktif maddeler, kesici-delici materyaller, toksinler ve tehlikeli kimyasallar gibi maddeleri de ihtiva etmektedirler.

Tıbbi atıkların kontrolsüz bir şekilde veya evsel nitelikli atıklarla beraber alıcı ortama bertaraf edilmesi sonucunda ekolojik döngüdeki her canlı sınıfı yaşamsal risk altına girmektedir.

Su kaynaklarının giderek kirlenmesi, tükenmesi, toprak yapısının bozulması, bazı hayvan türlerinin yok olması vb. gibi birçok çevre sorununun sorumlusu insanlardır. Enerji kaynaklarının ve su kaynaklarının sonsuz olmaması çevre sorunlarına bir çözüm bulunması hususunda devletlerin önlemler almasını gerektirmiştir. Tüm dünyada son y1llarda uygulanan önlemler ülkemizde de 
uygulanmaktadır. Türkiye de atık kaynaklı çevre kirliliği genellikle insan nüfusunun fazla olduğu ve sanayinin geliştiği bölgelerde yoğunlaşmıştır. Ancak bu durum ülkenin geri kalanında gelişmekte olan sanayi şehirlerini de kapsamaya başlamıştır. Van Türkiye'nin en kalabalık on dokuzuncu ilidir. Van bölgesi göller bakımından da önemli bir bölgedir. Hoşap Suyu, Memedik Çayı, Karasu, Bendimahi Çayı, Deliçay, Irşat Çayı ve Zilan Çayı gibi irili ufaklı birçok gölden başka Türkiye'nin en büyük gölü olan Van Gölü bu ildedir [15]. Van gerek alıcı ortamların sayısı ve önemi gerekse turizm alanındaki konumu itibari ile öncelikli alanlar içerisinde yer almaktadır. Bu çalışmanın amacı Van ilindeki tehlikeli atıkların mevcut potansiyelini belirlemek, şehrin tehlikeli atık yönetimi ile ilgili sorunlarını tespit etmek ve çözüm önerileri sunmaktır.

\section{MATERYAL VE METOT}

Çalışmanın yapılmasında, tehlikeli atıklar konusunda tamamlanmış projelerden [16], Van ili için daha önce kamu kuruluş ve kurumlarınca hazırlanmış çevre durum raporlarından [17,21] yararlanılmıştır. Kentin güncel atık potansiyeli ve verileri ile ilgili diğer bilgiler çeşitli haber sitelerinden [19,22] elde edilmiştir. Ayrıca Türkiye ve Van genelindeki tehlikeli atıklar ile ilgili istatistiki bilgiler Türkiye İstatistik Kurumunun raporlarından [23] elde edilmiştir.

Çalışmanın objektif açıdan değerlendirilebilmesi için elde edilen bilgilerin doğruluğu kıyaslamalı olarak tartışılmıştır. Ayrıca, çalışmanın sürdürülebilirliği ve uygulanabilirliği için geçerli olan yönetmelik ve kanunların uygulanma şekilleri incelenmiştir.

Atık yağların toplanması, depolanması ve bertarafı hususunda Avrupa Parlamentosu ve Konseyinin 19 Kasım 2008 tarihli ve 2008/98/EC sayılı atık yönergesinden yararlanılmıştır.

Bitkisel yağların kullanılması sonucu bitkisel atık yağların bertarafina ilişkin Atık Yönetimi Yönetmeliğinden yararlanılmıştır [5]. ÖTL'lerin alıcı ortama deşarjının önlenmesi, yeniden kullanılması ve bertarafi hususunda Ömrünü Tamamlamış Lastiklerin Kontrolü Yönetmeliğinden yararlanılmıştır [12]. Atık Elektrikli ve Elektronik Eşyaların yeniden kullanılması ve bertarafı hususunda Elektrikli ve Elektronik Eşyaların Kontrolü Yönetmeliğinden yararlanılmıştır [13].

Atık Pil ve Akümülatörlerin yeniden kullanılması ve bertarafi hususunda Atı Pil ve Akümülatörlerin Kontrolü Yönetmeliğinden faydalanılmıştır [8].

Tıbbi atıkların toplanması, depolanması ve bertarafı konusunda Tıbbi Atıkların Kontrolü Yönetmeliğinden faydalanılmıştır [14].

\section{ARAŞTIRMA BULGULARI}

\subsection{Atık Madeni Yağlar}

Miktarı gitgide artan atık madeni yağların Türkiye bilançosunu araştırmak için Petrol Sanayi Derneği (PETDER) tarafindan gerçekleştirilen 'Atık Madeni Yağ Arıtma Projesi için En Uygun Teknolojinin Seçimi' isimli proje kapsamında toplanan atık mineral yağların yıllık miktarları hesaplanmış ve Şekil 1'de verilmiştir [16].

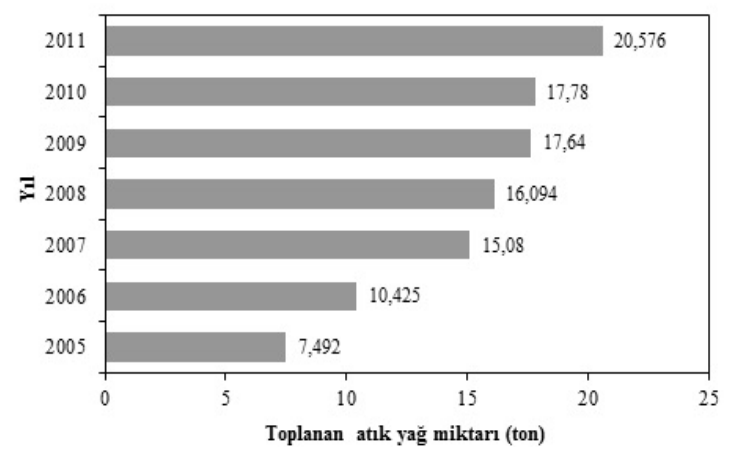

Şekil 1. PETDER Tarafından toplanan atık mineral yağların yıllık miktarları (ton) [16]

Şekil 1'den de görüleceği üzere gelişen teknoloji, hızlı nüfus artışı ve buna bağlı olarak gitgide kullanımı artan madeni yağların minimizasyonu, yeniden kullanılabilirliği ve zararsız bertarafı önem kazanmaktadır. 
Van ilinde bulunan ișletme ve tesislerden kaynaklanan sentetik motor, makine, şanzıman, hidrolik ve gres gibi madeni atık yağların tehlikeli atık sınıfına girmeleri sebebi ile yönetmeliğe uygun bir şekilde toplanması, taşınması, depolanmas1, bertaraf edilmesi ve geri dönüşümünün sağlanması hususunda madeni atık yağların sınıflarına ayrılarak geri kazanımına ya da bertarafına ilişkin kontrolü, denetlenmesi ve atık yağ beyan formalarının üretici tarafından Çevre il müdürlüğüne teslim edilmesi ve müdürlükçe izlenmesi çalışmaları yürütülmektedir.

Kentte organize sanayi bölgesinde bulunan ve kota uygulamasına dâhil olan bir adet işletme (Wanoil) mevcuttur. Ayrica, kentte makine parkı bulunan işletme ve kurumlara işletmelerinden çıkan atık yağların geçici depolanması ve sadece yetkisi bulunan kuruluşlara teslimi konusunda resmi yazı ile bilgilendirme yapılmış olup bu husustaki kontroller yapilmaktadir. 2009-2017 y1llar1 arasında kentte toplanan atık madeni yağ miktarları Şekil 2'de gösterilmiştir [17].

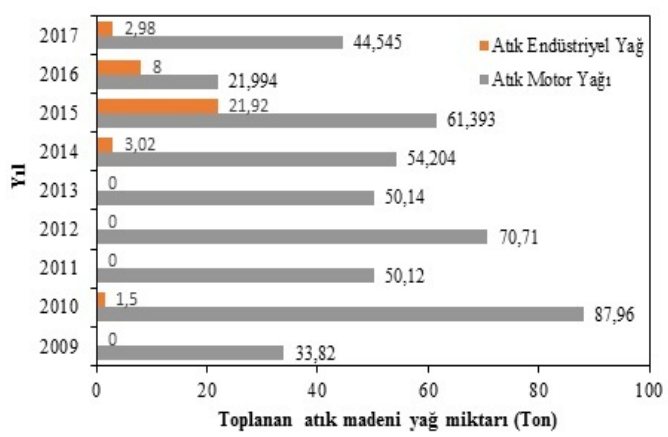

Şekil 2. Van İli'nde atık madeni yağ toplama miktarları [17]

Şekil 2'den görüldüğü gibi atık motor yağ miktarı ve atık endüstriyel yağ miktarı 2009-2017 yılları arasında değişkenlik göstermiş, toplanan atık yağ miktarı 2010 yılında en yüksek, 2016 yılında ise en düşük değere sahiptir. 2013-2015 yılları arasında toplanan atık yağ miktarı gittikçe artmış takip eden 2016-2017 yıllarında nispeten azalmıștır. 2013-2015 yılları arasında toplanan atık madeni yağ miktarları artması kentteki sanayi kurumlarının sayısının artması ile ilgili iken takip eden 2016-2017 yılları arasında toplanan atık madeni yă̆ miktarının nispeten azalması geri kazanılan atık madeni yağların artması ile ilişkilidir. Çizelge 3'te 2009-2017 yılları arasında atık madeni yağ geri kazanım ve bertaraf miktarları verilmiştir.

Çizelge 3. Van İli'nde 2009-2017 yılları arasında atık madeni yağ geri kazanım ve bertaraf miktarlar1 [17]

\begin{tabular}{|c|c|c|c|c|c|}
\hline Y11 & $\begin{array}{c}\text { Geri } \\
\text { kazanım } \\
(\mathrm{kg})\end{array}$ & $\begin{array}{c}\text { Nihai } \\
\text { bertaraf } \\
(\mathrm{kg})\end{array}$ & $\begin{array}{c}\text { İhracat } \\
(\mathrm{kg})\end{array}$ & $\begin{array}{c}\text { Stok } \\
(\mathrm{kg})\end{array}$ & $\begin{array}{c}\text { Atık } \\
\text { minimizasyonu } \\
(\text { Tesis içi })(\mathrm{kg})\end{array}$ \\
\hline 2009 & 33,820 & 950 & - & - & 33,820 \\
\hline 2010 & 89,456 & - & - & 2044 & 89,456 \\
\hline 2011 & 60,960 & - & - & 174 & 60,960 \\
\hline 2012 & 70,713 & - & - & 115 & 70,713 \\
\hline 2013 & 50,140 & - & - & 300 & 50,140 \\
\hline 2014 & 63,384 & 1700 & - & 430 & 63,884 \\
\hline 2015 & 86,313 & - & - & 4985 & 83,313 \\
\hline 2016 & 20,002 & - & - & 5118 & 21,193 \\
\hline 2017 & 47,525 & - & - & 300 & 50,140 \\
\hline
\end{tabular}

Çizelge 3'ten görüleceği üzere 2009 ile 2017 yılları arasında toplamda tesislerden çıkacak olan atık madeni yăg miktarının 537,085 kg olduğu, tesis içi minimizasyonu sağlanan atık yağ miktarının 523,619 kg olduğu, geri kazanılan miktarın $522,313 \mathrm{~kg}$ olduğu, nihai bertarafi sağlanan atık yağ miktarının $2650 \mathrm{~kg}$ olduğu görülmektedir. Elde edilen veriler 1şığında, 2009 yılından 2017 yılına kadar toplanan atık yağ miktarının \%97,25'inin geri kazanıldığ1, $\% 0,25$ 'inin nihai bertarafının sağlanabildiği $\% 2,5$ 'inin ise geri kazanım ya da bertarafının sağlanamadığı anlaşılmaktadır.

Sonuç olarak toplanan atık madeni yağların 20092017 yılları arasında neredeyse tamamının geri kazanıldığı ve buna ek olarak tesis içi geri kazanım ile atık yağ miktarının büyük miktarının tesis içi atık minimizasyonu ile sağlandığı açıktır.

\subsection{Bitkisel Atık Yağlar}

Atık yağların kontrolü yönetmeliğinin yürürlüğe girmesinden önce ülkemizde atık yağların yeniden kullanılabilirliğine ilişkin yapılmış çalışmalar neticesinde 2005 yılından 2014 yılına kadar toplanan atık bitkisel yağların miktarı 1858 ton dan yaklaşık 21.000 tona artmıştır (Şekil 3) [18]. 


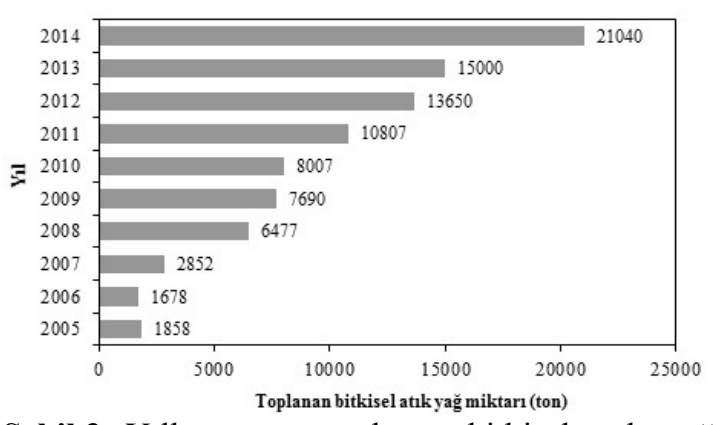

Şekil 3. Yıllara göre toplanan bitkisel atık yağ miktar1 [18]

Kentte bitkisel atık yağların geçici depolanması, bertarafı ya da geri kazanımına ilişkin bir tesis mevcut değildir. Ancak kentin farklı noktalarında, restoranlarında, okullarında, dinlenme tesislerinde, kurum ve kuruluşlarında bulunan atık yağ depolarından toplanan bitkisel nitelikli atık yağların toplanması ve taşınması faaliyetleri DEHA Bitkisel Atık Yağ Toplama ve Geri Kazanım San. ve Tic. A.Ş. ile KOLZA Biyodizel yakıt ve Petrol ürünleri San. Tic. A.Ş. lisanslı firmaları tarafindan 2016 yılından itibaren yürütülmektedir. 2016 yılı içerinde toplanan bitkisel nitelikli atık yağ miktarı $16,359 \mathrm{~kg}$ 'dır [17]. Söz konusu tesislerin her birinin 50.000 ton biyodizel üretimi kapasitesi bulunmakla birlikte biyodizel üretiminde bitkisel ham yağ ve atık bitkisel yağ ham madde olarak kullanılmaktadır. Kente en yakın geçici depolama merkezi Diyarbakır da bulunmaktadır.

\subsection{Atık Pil ve Akümülatörler}

Atık pillerin yerinde, ayrı toplanması, depolanması, taşınması ve bertarafında Çevre ve Şehircilik bakanlığı tarafından 2013 yılında imzalanmış protokol ile yetki sahibi olan tek kuruluş TAP (Taşınabilir Pil Üreticileri ve İthalatçıları Derneği)'dir. TAP 2013 yılından itibaren atı nitelikteki pillerin toplanması faaliyetlerine başlamıştır. Faaliyetler kapsamında atık pillerin geri dönüşümünün önemi hakkında eğitim seminerleri verilmiş ve 450 adet atık pil toplama kutusu MEB (Milli Eğitim Bakanlığı)'e bağlı tüm okullarda, bazı özel okullarda ve Van yüzüncü yıl üniversitesinin tüm fakültelerine koyulmuştur [19]. Ayrıca şehir merkezinin farklı noktalarına da atık pil toplama kutuları bırakılmıştır. TAP tarafından 2013 yılından 2019 yılına kadar ülke genelinde $178.556 \mathrm{~kg}$ atık pil toplanmıştır bunun 725 kg'1 kentimizden toplanan atık pil miktarıdır [19] (Şekil 4).

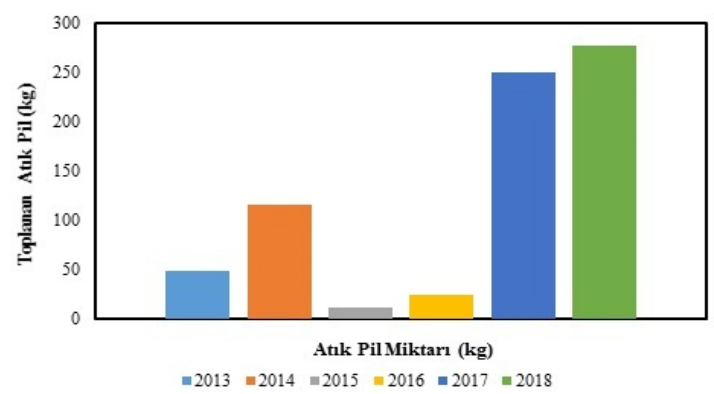

Şekil 4. 2013-2018 yılları arasında kentte toplanan atık pil miktarının dağlımı

Şekil 4'ten de görüleceği üzere her ne kadar 2015-2016 yıllarında toplanan atık pil miktarında düşüş gözlenmişse de genel itibari ile artan bir ivme ile geri dönüşüme kazandırılan pil miktarı kentte artış göstermektedir. Toplanan piller TAP tarafından yetkilendirilmiş 'Exitcom Recycling, Anel Doğa ve Ekoden' firmalarının lisanslı araçları tarafindan geri kazanım ve bertaraf tesislerine ulaştırılmaktadır. Ayrıca kentte atık mahiyetinde bulunan akümülatörler de aynı şekilde lisanslı araçlarla ayrı olarak toplanmaktadır. Şekil 5'te 2011-2016 yılları arasında kentte toplanan atık akü miktarı gösterilmektedir [20].

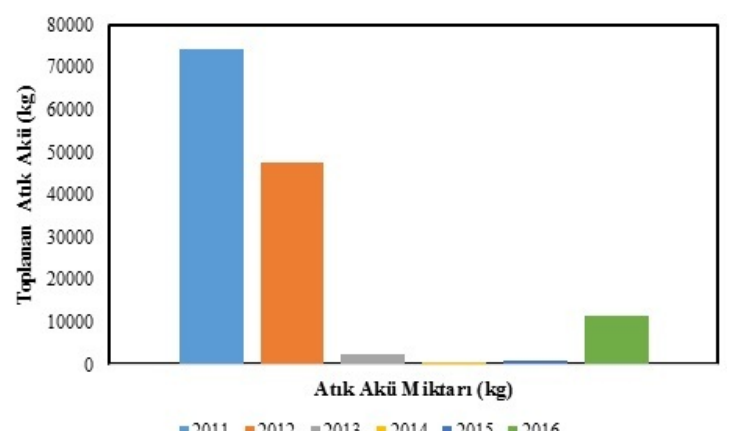

Şekil 5. 2011-2016 yılları arasında kentte toplanan atık akü miktarının dağlımı [20]

Şekil 5'ten görüldüğü gibi toplanan atık akü miktarının en yüksek olduğu yıl 2011 onu takiben 2012 yılıdır. $\mathrm{Bu}$ durum 2011 yılından önceki 
yıllarda toplanan ve bertaraf ya da geri kazanımı sağlanamamış hurda niteliğinde biriktirilen atık akü miktarı ile ilişkilidir. 2013-2015 yılları arasında ise toplanan atık akü miktarının düşük olması bu atıkların düzenli olarak toplanması ile ilgili iken 2016 yılında 11.514 kg'a yükselen bu durum kentin aldığ 1 göçler (Suriye, Afganistan vb. ülkelerden gelen göçmenler) ile artan yerel kent nüfusu ve buna bağlı olarak artan motorlu araç kullanımı ile ilişkilidir. Kentte bertaraf/geri kazanım tesisi bulunmamaktadır.

\subsection{Atık Elektrikli ve Elektronik Eşyalar (AEEE)}

Çevre ve Şehircilik Bakanlığı'nın 2015 verilerine göre [21] ülkemizde yaklaşık 28 bin ton evsel elektronik atık geri dönüştürülmüştür.

Kentte AEEE İşleme Tesisi bulunmamaktadır. Bu nitelikteki atıklar ömrünü tamamlamış atık elektronik eşyaları toplayan firmalar (Arçelik, Beko, Vestel vb.) dışında bu atık elektronik aletlerin içerisinde bulunan ve tekrar kullanılabilir nitelikteki malzemeleri ayrıştıran şahıs ya da küçük esnaf tarafından gerçekleştirilmektedir.

\section{5. Ömrünü Tamamlamış Lastikler (ÖTL)}

Kentte "Ömrünü Tamamlamış Lastiklerin Kontrolü Yönetmeliğii” kapsamında lisanslı geri kazanım tesisi bulunmamaktadır. Ancak toplanan ÖTL'ler lisanslı geri dönüşüm tesislerinde enerji ve hammaddeye dönüştürülerek ekonomiye kazandırılmaktadır. Ayrıca geri dönüşüme kazandırılan lastiklerin tıraşlanması sırasında çıkan hammadde yürüyüş parkuru, ayakkabı tabanı ve paspas yapımında kullanılması için fabrikalara gönderilmektedir, bu şekilde kent ekonomisine yılda ortalama 2,5 milyon lira kazandırılmaktadır [22]. Ömrünü tamamlamış bir lastiğin geri kazanım sürecinde; yaklaşık \%73 oranında granül kauçuk malzemesi, \%19 oranında çelik tel, \%8 oranında ise tekstil ve diğer maddeler geri kazandırılmaktadır. Ayrıca ömrünü tamamlamış atık lastikler ilçe belediyeleri tarafından toplanarak çeşitli tasarım ve peyzaj uygulamalarında da kullanılmaktadır. 2016 yılında kentte 2443 kg ÖTL beyanı yapılmıştır. LASDER Lastik Sanayicileri Derneği İktisadi İşletmesi tarafından, 01 Ocak 2019-31 Aralık 2019 tarihleri arasında, ömrünü tamamlamış lastiklerin (ÖTL) toplama ve taşıma işlerini Van için 'Umut Atık Toplama' ve 'Mesut Emek İletişim’ isimli firmaların yapacağı belirlenmiştir.

\subsection{Tıbbi Atıklar}

Türkiye İstatistik Kurumu (TÜİK) 2010-2014 verilerine göre (Çizelge 4) hasta başına çıkan ortalama tıbbi atık miktarı (kamu-özel-üniversite hastaneleri) 2010 yılında $0,20 \mathrm{~kg}, 2012$ yılında $0,20 \mathrm{~kg}$ ve 2014 yılında $0,19 \mathrm{~kg}$ 'dır [23]. Bu atık oranı gelişmiş ülkelerde, hasta başına 1,1 ile $1,2 \mathrm{~kg}$ olup bunun yaklaşık 0,4 ile 0,5 kg' 1 tehlikeli atık özelliğindedir [24].

Çizelge 4. Türkiye'de hasta başına çıkan ortalama tıbbi atık miktarı [23]

\begin{tabular}{|l|c|c|c|c|c|c|c|c|c|}
\hline \multirow{2}{*}{ Sağlık kurumu } & \multicolumn{2}{|c|}{$\begin{array}{c}\text { T1bbi atığ yerinde ve ayrı } \\
\text { toplanan kurulus sayıs }\end{array}$} & \multicolumn{2}{c|}{ T1bbi atık miktarı (kg/y1l) } & \multicolumn{2}{c|}{$\begin{array}{c}\text { Hasta başına ortaya çıkan ortalama } \\
\text { tıbbi atık miktarı (kg/gün) }\end{array}$} \\
\cline { 2 - 12 } & 2010 & 2012 & 2014 & 2010 & 2012 & 2014 & 2010 & 2012 & 2014 \\
\hline Sağlık bakanlığ1 & 866 & 869 & 894 & 322,63 & 303,83 & 752,83 & 0,14 & 0,14 & 0,13 \\
\hline Özel hastaneler & 470 & 515 & 538 & 806,81 & 542,31 & 910,51 & 0,25 & 0,27 & 0,28 \\
\hline $\begin{array}{l}\text { Üniversite } \\
\text { hastaneleri }\end{array}$ & 62 & 65 & 66 & 837,11 & 82,71 & 831,71 & 0,72 & 0,56 & 0,53 \\
\hline Toplam & 1398 & 1449 & 1498 & 966,55 & 928,86 & 495,07 & 0,20 & 0,20 & 0,19 \\
\hline
\end{tabular}

Çizelge 4'ten elde edilen veriler den de anlaşılacağı üzere Türkiye'nin tıbbi atık miktarının gelişmiş ülkelerdeki kadar yüksek olmadığ 1 ancak artan insan nüfusu ve buna bağlı olarak artacak hasta sayısı da göz önüne alındığında tıbbi atıkların yönetiminin oldukça önemli bir yere sahip olduğu açıktır.

Van İli, merkez Tuşba İlçe'si, Bey Üzümü Mah., Özalp yolu üzeri hoş geldik mevkiindeki Rohan 
temizlik peyzaj otm.tic.ve san. Ltd. Şti tarafından kurulan tıbbi atık sterilizasyon tesisi 2009 y1lında faaliyete alınmıştır (Şekil 6). Yaklaşık $3000 \mathrm{~m}^{2}$ alana kurulu olan tesise Şırnak ve Hakkâri illerinden gelen tıbbi atıklar sterilize edilmektedir.

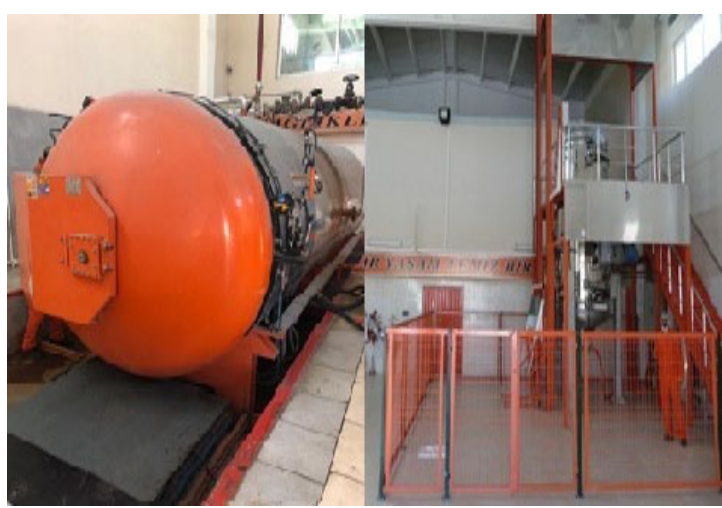

Şekil 6. Tıbbi atık sterilizasyon tankı (sol), Tesis içi genel görünüm (sağ)

Kent merkezindeki tıbbi atık üreten tüm kuruluşlardan (Çizelge 5) her gün, kentteki diğer ilçelerden ortalama haftada 3 defa (Pazartesi, Çarşamba ve Cuma) tıbbi atık toplanmaktadır.

Çizelge 5. Kent merkezinde bulunan ve Tibbi atıkların toplamının gerçekleştiği kuruluşlar ve sayıları [17]

\begin{tabular}{|l|c|}
\hline Kurum Ad1 & Sayıs1 \\
\hline Acil sağlık hizmeti kurumu & 28 \\
\hline Toplum sağlık merkezi & 14 \\
\hline Aile sağlık merkezi & 83 \\
\hline Devlet hastanesi & 9 \\
\hline Dal Hastanesi & 1 \\
\hline Ağız-Diş Sağlı̆̆ı Merkezi & 1 \\
\hline Tıp Fakültesi & 1 \\
\hline Diş Hekimliği Fakültesi hastanesi & 1 \\
\hline Özel Hastane & 4 \\
\hline Ağı Diş Sağlığı polikliniği & 34 \\
\hline Diş Protez Laboratuvarı & 14 \\
\hline Biyokimya Laboratuvarı & 1 \\
\hline Eczane & 143 \\
\hline İşitme Merkezi & 6 \\
\hline Optik İşletmesi & 16 \\
\hline Güzellik Salonu & 8 \\
\hline Röntgen Görüntüleme merkezi & 5 \\
\hline Özel Muayene & 119 \\
\hline Ecza Deposu & 5 \\
\hline
\end{tabular}

Günlük 8-10 ton atık sterilizasyon kapasiteli tesiste işlemler Tıbbi Atıkların Kontrolü Yönetmeliğine uygun olarak yürütülmektedir. Toplanan tıbbi atıklar öncelikle radyoaktivite ölçer cihazlar ile kontrol edilerek tartıldıktan sonra tesise tıbbi atık toplayan toplam lisanslı araçlar (6 adet) ile getirilmektedir, tesis girişinde tekrar radyo aktifliği ölçülen atıkların kontrolü yapıldıktan sonra radyoaktif içerikli atıkların tesise girişi engellenmektedir. Tesise girişi sağlanan tıbbi atıklar $150{ }^{\circ} \mathrm{C}$ 'deki su buharı ile sterilize edilmektedir. Sterilize edilip evsel atık niteliği kazandırılan atıklar kentte bulunan vahşi depolama alanına taşınarak bertaraf edilmektedir. Tesiste bir günde yaklaşık 2,5-3 ton arasında tıbbi atık sterilizasyonu yapılmaktadır. Van Büyükşehir Belediyesi, Çevre Koruma ve Kontrol Daire Başkanlığı tarafından rutin olarak tesisin proses işleyişi, çalışanların periyodik eğitim çizelgeleri ve tıbbi atık yönetim planları denetlenmektedir. Ayrıca çalışanların sağlık kontrollerinin yapılıp yapılmadığı, sterilizasyon işleminin geçerliliği ve sterilizasyon cihazının basınç/sıcaklık değerlerinin uygunluğu da denetlenmektedir. Sterilizasyon işleminin verimliliği hususunda Çevre ve Şehircilik Bakanlığı tarafından 3 ayda bir 'biyolojik indikatör testi' neticesinde ve tesis içinde yapılan 'kimyasal indikatör testi' sonucunda tesisin \%99,99 oranında mikrobiyolojik faaliyetleri durdurduğu sonucuna varılmıştır. Tıbbi atık sterilizasyon tesisinin henüz faaliyete geçmediği 2009 yılının ilk yarısına kadar diğer evsel atıklardan ayrı bir şekilde kireçle gömme yöntemine göre bertaraf edilmekte idi. Çizelge 6'da 2010-2017 yılları arasında kentte toplanan tıbbi atık miktarları gösterilmiştir [17].

Çizelge 6. Van İli'nde yıllara göre tıbbi atık miktar1 (ton) [17]

\begin{tabular}{|c|c|c|c|c|c|c|c|}
\hline 2010 & 2011 & 2012 & 2013 & 2014 & 2015 & 2016 & 2017 \\
\hline 972 & 822 & 977 & 828 & 892 & 1196,3 & 989,7 & 907,6 \\
\hline
\end{tabular}

Çizelge 6'da görüldüğü gibi 2010-2017 yılları arasında toplanan tıbbi atık miktarları dalgalanma gösterse de kentte yıllık ortalama 800-1000 ton aralığında tıbbi atık toplanmaktadır. Kentte hali hazırda bulunan katı atık vahşi depolama sahasının şehre verdiği zararlardan ötürü (Rüzgarla çöplerin şehre dağılması, deponi sahası yakınında bulunan 
yeraltı su kaynaklarına ve yüzey suyu kaynaklarına (Sıhke gölü) sızıntıların olması, koku vb.), yeni bir düzenli katı atık deponi sahasının kurulması için 31 Kasım 2018 tarihinde ihale yapılmış ve elektrik enerjisinin de üretilebileceği yeni katı atık entegre tesisi kurulması hususunda Panda Alüminyum A.Ş.-Üregen Taahhüt İnşaat Mühendislik Danışmanlık Madencilik Sanayi İç ve Dış Tic. Ltd. şirketi ortaklığı işi üstlenmiştir. İki aşamada hayata geçirilmesi planlanan projenin ilk aşamasında mevcut vahşi depolama alanının ıslah edilerek yeşillendirilmesi ve alanın üzeri kapatılarak elde edilen lentfil gazının (Çöp Gazı) elektrik enerjisine dönüştürülmesi planlanmaktadır. İkinci aşamada ise atık alanında Avrupa Birliği (AB) standartlarına uygun entegre tesis kurulacaktır. Ayrica buraya getirilen organik atıklar, fermantasyon sistemi ile büyük tanklarda $55^{\circ} \mathrm{C}$ sıcaklıkta bekletilerek oluşan biyogazdan elektrik enerjisi elde edilecek. Atıklardan geriye kalan malzemelerin ise kompost yapılarak gübre yapımında kullanılması sağlanacak. Bu sayede sıfır atık ile işlemler devam edecek. Tehlikeli atık sınıfına giren tıbbi atıkların 'tıbbi atık sterilizasyon tesisin' de sterilize edildikten sonra Tuşba İlçesi, Beyüzümü Mahallesinde yapılacak olan 3,2 milyon $\mathrm{m}^{3}$ düzenli depolama bölümüne sahip olan 'katı atık entegre tesisi' ne daha güvenli bir şekilde bertarafı sağlanacaktır.

\section{SONUÇLAR VE ÖNERIILER}

Kentte atık madeni yağların neredeyse tamamının geri kazanıldığı, kazanılan atık yağın büyük miktarının tesis içi atık minimizasyonu ile sağlandığı göz önünde bulundurularak ilerleyen yıllarda taşıma, geçici depolama vb. gibi süreçlerden kaynaklanan masrafları minimize etmek ve kent ekonomisine katkı sağlayabilmek adına 'Atık Yağ Geri Kazanım Tesisi' kurulumu hususunda gerekli çalışmaların başlatılması çözüm teşkil edebilir. Beslenmenin insanlığın temel ihtiyacı olduğu göz önünde bulundurulduğunda kayıtlara geçen kentten toplanan bitkisel atık yă miktarının tüketilen bitkisel yağlardan az olması sebebi ile restoran, kafe, devlet kurum ve kuruluşlarının yemekhaneleri, otel, hastaneler vb. gibi yerlerin daha çok teşvik edilmesi, gerek halkın gerekse kurum ve kuruluşların bilinçlendirilmesi konusunda eğitim ve seminerlerin verilmesi, atık yağ toplama noktalarının kentin tüm ilçe ve köylerine konulması, toplanan atık yağ karşılığında teşvik amaçlı ödüllerin verilmesi gerekmektedir. Bu şekilde geri dönüştürülebilir nitelikli toplanan atık bitkisel yağ miktarı artacak ve biyodizel gibi çevre dostu yakıtlara dönüşümün oranı artacaktır, böylelikle ülke ekonomisine katkı sağlanmış olacaktır. Kentte 2013 yılından 2019 yılına kadar toplanan atık pil ve akümülatörlerin sayısı (edinilen verilere göre) zaman içerisinde artış gösterse de kent nüfusunun 1.123.784 olduğu göz önüne alındığında bu verilerin gerçekte harcanan atık pil ve akümülatör sayısını yansıtmadığı öngörülmektedir. Kentin 2019 y1lı planlaması dikkate alındığında atık pil ve akümülatörlerin değerlendirilebileceği tesis kurulumunun söz konusu olmadığı görülmektedir. $\mathrm{Bu}$ bağlamda atık pil ve akümülatörlerin kullanımının ve ayrı toplanmasının öneminin kent halkına seminer ve eğitimlerle vurgulanması gerekmektedir. Bilinçlenen halk atık pil ve akümülatörlerin gerçeği yansıtacağ toplanmasına katkı sağlayacaktır böylelikle taşınabilir türdeki atık pillerin geri dönüşümünden çinko ve çinko bileşikleri, manganez birleşikleri, ferromangan, ferronikel, nikel, kadmiyum ve kadmiyum birleşikleri, lityum, gümüş, kobalt ve büyük kapasiteli birkaç tesiste de az miktarlarda nadir toprak elementlerinin geri dönüştürülmesi mümkün olacak ve ülke ekonomisine pozitif katkı sunulacaktır.

Kentte AEEE işleme tesisi bulunmamakla birlikte bu nitelikteki atıklar ömrünü tamamlamış atık elektronik eşyaları toplayan firmalar (Arçelik, Beko, Vestel vb.) dişında bu atık elektronik aletlerin içerisinde bulunan ve tekrar kullanılabilir nitelikteki malzemeleri ayrıştıran şahıs ya da küçük esnaf tarafindan gerçekleştirilmektedir. $\mathrm{Bu}$ durumla beraber atık malzemeden tam bir yeniden kullanımı sağlamamakla beraber AEEE içerisindeki bakır, altın ekipmanların, motor vb. gibi kıymetli sayılabilecek malzemelerin alınması nihayetinde kalan atık, herhangi bir plan ve yönetmelik dışında evsel atık niteliğindeki çöplere atılmaktadır. $\mathrm{Bu}$ durumun bir sonucu olarak kontrolsüz ve emniyetsiz tehlikeli atıklar ekolojik döngüye katılmaktadır. Kentteki bu soruna çözüm 
olarak ülkemizde çevre mevzuatı kapsamında gerekli izin ve lisansları bulunan firmalar ile iş birliği içerisine girilerek bir protokol imzalanması ve AEEE'lerin il genelinde etkin toplanması için; büyük şehir belediyesinin, ilçe belediyelerinin çalışmalarını koordine etmesi ve konuyla ilgili yürütülen bilgilendirme ve eğitim faaliyetlerini desteklemesi gerekmektedir. $\mathrm{Bu}$ şekilde AAEE'lerin işlenmesinde ana hammadde olarak hurdaya çıkmış işlemciler, atık kablolar ve elektronik kartların işlenerek ihtiva ettikleri değerli metallerin (demir içerikli/altın bakır içerikli malzemeler) külçe, granül veya levha haline getirilmesi ve satışa sunulması mümkün olacak böylece ülke kalkınmasına katkı sağlanarak, kentte tehlikeli atık niteliğinde tehdit oluşturan ve bertarafı bir sorun haline gelen AAEE'ler için bir çözüm üretilmiş olacaktır.

Kentte ÖTL'in geri kazanım tesisi bulunmamakla birlikte 01 Ocak 2019-31 Aralık 2019 tarihleri arasında, ömrünü tamamlamış lastiklerin (ÖTL) toplama ve taşıma işlerinin kent için lisanslı firmaların yapacağı belirlenmiştir. Ancak kentte trafiğge kayıtlı araç sayısının 2018 Kasım ayı sonu itibarıyla 79.196 olduğu göz önüne alındığında geri dönüşüme dâhil olması gereken daha fazla ÖTL olduğu sonucu çıkmaktadır. Bu hususta Van otomobil sanayi sitesinde ÖTL toplayan ve kendi çabalarıyla yeniden kullanım sağlayan/depolayan kuruluşların bilgilendirilmesi, broşürler ve afişler ile görsel olarak desteklenen eğitimlerle aynı zamanda halkta farkındalık yaratılması, lisanslı araçların ücretsiz ve ayın belirli günlerinde periyodik olarak toplama işlemlerini gerçekleştirmesi ve bu kuruluşların geri dönüşüme katkı sağlamaları neticesinde kg ÖTL başına belirli miktarlarda maddi destek sağlanması gerekmektedir. $\mathrm{Bu}$ şekilde ÖTL'in toplanması konusunda halk teşvik edilmiş olacaktır.

Tehlikeli atık sınıfına giren tıbbi atıkların kentte aktif olarak faaliyet gösteren 'tıbbi atık sterilizasyon tesisin' de sterilize edildikten sonra vahşi depolanan bu atıkların sebep olduğu sorun çözülmüş olup yapımına başlanan 'katı atık entegre tesisi' ne daha güvenli bir şekilde bertarafı sağlanacaktır. Kente çevre illerden de tıbbi atık girişinin olduğu göz önüne alındığında kentin ekolojik döngüye pozitif yönde mühim katkıları olduğu açıktır.

Sonuç olarak kentin geri dönüştürülebilir nitelikli tehlikeli atık potansiyelinin iyi olduğu, büyük şehir belediyesi-Çevre ve Şehircilik Bakanlığg iş birliğinde öncelikli olarak potansiyeli yüksek atık elektrikli-elektronik eşyalar ve atık yağlar için geri dönüşüm tesisinin kurulması faydalı olacaktır. Lisanslı firmalar tarafından toplanan diğer tehlikeli ve geri kazanılabilir nitelikli atıklar için ise şu aşamada eğitici seminer ve atık başına teşvik gibi uygulamalarla bu atıkların toplanma miktarları arttırılabilir.

Ayrıca yazarın yapmış olduğu araştırmalara göre Van İli için kentsel nitelikli tehlikeli atık envanteri hakkında kapsamlı bir çalıșma mevcut değildir. Ancak kentte kurulmakta olan katı atık entegre tesisi için yapılan evsel nitelikli katı atık envanter çalışmaları mevcuttur. Atıkların envanteri oluşturulurken mevcut durum itibarıyla konutlar, işyerleri vs. şeklinde bir ayrıma gidilmemiştir. Dolayısıyla Van büyük şehir belediyesinin kentsel nitelikli tehlikeli atık kompozisyon çalışması yaparak böyle bir veriyi elde etmesi atık yönetimi konusunda önemli planlar yapılmasının önünü açacaktır.

\section{KAYNAKLAR}

1. Hill, M.K., 2010. Understanding Environmental Pollution. Cambridge University Press.

2. Schaefer, M.E., 1991. Hazardous Waste Management, Dental Clinics of North America, 35(2), 383-390.

3. Chaaban, M. A., 2001. Hazardous Waste Source Reduction in Materials and Processing Technologies. Journal of Materials Processing Technology, 119(1-3), 336-343.

4. Muralidharan, K., Vasudevan, D., 2011. Performance, Emission and Combustion Characteristics of a Variable Compression Ratio Engine Using Methyl Esters of Waste Cooking Oil and Diesel Blends. Applied Energy, 88(11), 3959-3968. 
5. Atık Yağların Kontrolü Yönetmeliği, 2008. Resmi Gazete, Resmî Gazete Tarihi: 30.07.2008 Resmî Gazete Sayısı: 26952.

6. Atık Yönetimi Yönetmeliği, 2015. Resmi Gazete, Resmi Gazete Tarihi: 02.04.2015, Resmi Gazete Sayısı: 29314.

7. Çevre ve Orman Bakanlığı, Çevre Yönetimi Genel Müdürlüğü, 2010. Atık Yönetimi Dairesi Başkanlığı, Bitkisel Atık Yağların Yönetimi.

8. Atık Pil ve Akümülatörlerin Kontrolü Yönetmeliği, 2004. Resmi Gazete, Resmi Gazete Tarihi: 31.08.2004, Resmi Gazete Sayıs1: 25569.

9. Öztürk, M., 2005. Pil/Akü Kullanımı ve Atık Piller ile Akülerin Zararları, Yıldız Teknik Üniversitesi, Çevre ve Orman Bakanlığı, http://www.cevreorman.gov.tr/belgeler/piller.p df.

10. Ozturk, D., Şahan, T., Dişli, E., Aktaş, N., 2014. Optimization with Response Surface Methodology (RSM) of Adsorption Conditions of $\mathrm{Cd}$ (II) ions from Aqueous Solutions by Pumice, Hacettepe Journal of Biology and Chemistry, 42(2), 183-192.

11. Batır, B., 2002. Türkiye için Kullanılmış Lastik Yönetimi Araştırması, İstanbul Teknik Üniversitesi, Fen Bilimleri Enstitüsü, Yüksek Lisans Tezi. 23, İstanbul.

12. Ömrünü Tamamlamış Lastiklerin Kontrolü Yönetmeliği, 2006. Resmi Gazete, Resmi Gazete Tarihi: 25.11.2006, Resmi Gazete Sayısı: 26357.

13. Atık Elektrikli ve Elektronik Eşyaların Kontrolü Yönetmeliği, 2012. Resmi Gazete, Resmi Gazete Tarihi: 22.05.2012, Resmi Gazete Sayıs1: 28300.

14. Tıbbi Atıkların Kontrolü Yönetmeliği, 2017. Resmi Gazete, Resmi Gazete Tarihi: 25.01.2017, Resmi Gazete Sayısı: 29959.

15. Yiğit, A., İrak, Z. T., Öztürk, D., Öztürk, E., Alpaslan, D., Şahan, T., Aktaş, N., 2017. Van Gölü Suyunun İyon Karakterizasyonuyla $\mathrm{Su}$ Kalitesinin Belirlenmesi, Iğdır Üniversitesi Fen Bilimleri Enstitüsü Dergisi, 7(4), 169-179.

16. Petrol Sanayi Derneği (PETDER), 2012. Selection of the Most Appropriate Technology for Waste Mineral Oil Refining Project, Technical Research Report.
17. Çevre ve Şehircilik İl Müdürlüğü, 2018. Van İli 2017 Yılı Çevre Durum Raporu, Çevre Yönetimi ve Denetimi Şube Müdürlüğü Van.

18. Yanmaz, V., 2016. Bitkisel Atık Yağların Yönetimi, Çevre ve Şehircilik Bakanlığı.

19. https://www.tap.org.tr/campaigns/tap-okulkampanyasi-2018-van/ (erişim tarihi: 01.04.2019).

20. Çevre ve Şehircilik İl Müdürlüğü, 2017. Van İli 2016 Yılı Çevre Durum Raporu, Çevre Yönetimi ve Denetimi Şube Müdürlüğü, Van.

21. Çevresel Etki Değerlendirmesi, İzin ve Denetim Genel Müdürlüğü Çevre Envanteri ve Bilgi Yönetimi Dairesi Başkanlığı, 2016. Türkiye Çevre Durum Raporu, Ankara.

22. http://www.hurriyet.com.tr/vandaomrutamamlanmis-lastikler-ekonomiye-kaz40882146 (erişim tarihi: 01.02.2019).

23. Türkiye İstatistik Kurumu (TUİK), 2015. Sağlık Kuruluşları Atık İstatistikleri, 18781.

24. Akbolat, M., Işsı, O., Dede, C., Çimen, M., 2011. Sağlık Çalışanlarının Tıbbi Atık Bilgi Düzeylerinin Değerlendirilmesi, Acıbadem Üniversitesi, Sağlık Bilimleri Dergisi, 2(3), 131-140. 